\title{
Pancreatic, hepatic, and renal histopatholological changes in thymoquinone- treated streptozotocin-induced diabetic male rats.
}

Jabbar A.A. Al-Sa'aidi; ${ }^{1}$ BS, MS, PhD, Prof. Physiol.; Hashim M.A. Kareem ${ }^{2}$; BS, MS, PhD, Asst. Prof. Histol.; Wijdan T.M. Al-Tameemi²; BS, MS, Asst. Prof. Histol.

${ }^{1}$ Dept. Physiol., College of Pharmacy, Al-Qadisiya University.

${ }^{2}$ Dept. Biology, College of Science, Al-Qadisiya University.

\begin{abstract}
The present study has been conducted to investigate the potency of thymoquinone (TQ) in ameleorating the pathological changes of pancreas, liver, and kidneys in streptozotocin-induced diabetic male rats. Sixty five adult male rats (aged 56 days and weighted 138 $\pm 8.8 \mathrm{~g}$ ) were subjected to five equal groups (13 male rats each), non-diabetic control and four diabetic groups. Diabetes was induced by single injection with streptozotocin ( $60 \mathrm{mg} / \mathrm{kg}$ b.w., i.p.). Rats $\geq 200 \mathrm{mg} / \mathrm{dl}$ of blood glucose were used as diabetic. Diabetic groups (DM, TQ50, TQ100, and DMI) were drenched with drinking water, TQ $(50 \mathrm{mg} / \mathrm{kg}, \mathrm{bw})$, TQ $(100 \mathrm{mg} / \mathrm{kg}$, bw), or injected with insulin (4 IU/animal), respectively, for 6 weeks. Twenty four hours after the last day of experiment, male rats has been anaesthesized, sacrificed, and pancreatic, liver, and kidney tissues were removed and fixed in formalin $(10 \%)$ for histopathological examination. Histological findings of thymoquinone treated (TQ50 and TQ100 groups) pancreases revealed normal cellularity of islets of Langerhans and normal exocrine tissue except few congestion, whereas those obtained from non treated diabetic rats (DM group) showed complet impairment of some islands and highly destructed of others. Normal hepatic architecture with the appearance of radiating shape around the central vein, has been shown in the section obtained from thymoquinone treated diabetic rats (TQ50 and TQ100 groups) except few congestion, obvious regeneration and mitotic division in the nuclei of hepatocytes. Sections obtained from non treated diabetic male rats (DM group) showed sever congestion, large thrombi in the hepatic tissue, and loss of hepatic architecture with sever hemorrhage, degeneration in hepatocytes, and dilation of sinusoids. Section obtained from kidneys of thymoquinone treated diabetic rats (TQ50 and TQ100 groups) reveales normal renal convoluted tubules with normal epithelium of the tubules and high cellularity of glomeruli. Whearas those obtained from non treated diabetic male rats (DM group) revealed dilation of renal convoluted tubules with necrosis in the epithelium of the tubules and sever hemorrhage in the renal tissue. It can be concluded that drenching of $100 \mathrm{mg} / \mathrm{kg}$ of TQ for 6 weeks has potent ameliorating and regenerative effect of pancreas, liver, and kidneys in experimentally-induced diabetic male rats.
\end{abstract}


Key words: Thymoquinone, Nigella sativa, diabetes mellitus, histopathology.

\section{Introduction}

Plants have long been used to treat many ailments. Medicinal plants used to treat hyperglycemic conditions are of considerable interest for ethno-botanical community as they are recognized to contain valuable medicinal properties in different parts of the plant. The active principles of many plant species are isolated for direct use as drugs, lead compounds or pharmacological agents (1). Traditional plant medicines or herbal formulations might offer a natural key to unlock diabetic complications (2). Of the several indigenous plants used in the treatment of DM among middle east countries is Nigella sativa. The Holy Prophet Muhammad appreciated the black seed at many places by saying that it is a remedy for every illness except the death (3). Seeds of Nigella sativa contain a considerable amount of fixed and volatile oils (4), proteins, alkaloids and saponins $(5,6,7)$. The oil and the seed constituents, in particular thymoquinone, have shown potential medicinal properties in traditional medicine (8). Most of the pharmacological activities are attributed to the presence of thymoquinone as an active component (9). Thymoquinone possess antioxidant effects through enhancing the oxidant scavenger system as well as its potent antiinflammatory mediators prostaglandins and leukotriens (8).

Meral et al., (10) concluded that $N$. sativa might be used in diabetic patients to prevent lipid peroxidation, increase antioxidant defense system activity and also to prevent the liver damage. Hosseinzadeh et al. (11) also reported that thymoquinone and $N$. sativa oil may have protective effects on lipid peroxidation process in rat hippocampus. Diets with $N$. sativa fixed oils $4 \%$ or $N$. sativa essential oils $0.3 \%$ were found safe in rats as serological indices like liver and kidney functioning tests, serum protein profile, level of cardiac enzymes, electrolytes balance, red and white blood cells remained in the normal ranges (12).

Kanter et al. $(13,14)$ investigated the effect of $N$. sativa on histopathology of pancreatic betacells, in streptozotocin-induced diabetic rats. They concluded that $N$. sativa treatment exerts a therapeutic protective effect in diabetes by decreasing oxidative stress and preserving pancreatic beta-cell integrity. It was also suggested that $N$. sativa may be clinically useful for protecting betacells against oxidative stress (15). The pharmacological actions of the seeds of $N$. sativa that have been reported include protection against nephrotoxicity and 
hepatotoxicity induced by either disease or chemicals $(6,16,17)$.

\section{Materials and methods}

1. Experimental rats: Mature male Sprague-Dawley rats have been used in the experiment, and were allowed one week to 2. with light on at 06:00 a.m and off at 06:00 p.m throughout the experimental period.

3. Preparation of TQ suspension: TQ suspension at a dose of $50 \mathrm{mg} / \mathrm{kg}$ bw (10) was prepared by disolving $5 \mathrm{mg}$ of TQ powder in $1 \mathrm{ml}$ of drinking water to be used as $5 \mathrm{mg} / 100$ $\mathrm{g}$ bw, so that each $100 \mathrm{~g}$ bw will need drenching $1 \mathrm{ml}$ of TQ suspension. For eg: adult male rat of $150 \mathrm{~g}$ bw must be drenched $1.5 \mathrm{ml}$ of TQ suspension which contain 7.5 $\mathrm{mg}$ of TQ powder $(5 \mathrm{mg}$ in $1 \mathrm{ml} / 100 \mathrm{~g}$ bw or $50 \mathrm{mg}$ in $10 \mathrm{ml} / \mathrm{kg} \mathrm{bw})$.

\section{Induction of diabetes in rats:} According to Mansford and Opie (18), diabetes has been inducted in 52 male rats (weighted $138 \pm 8.8 \mathrm{~g}$ and aged 56 days) by injection of single dose of sitriptozotocin; SZT (Sigma Aldrich, England) $(60 \mathrm{mg} / \mathrm{kg}$ b.w., i.p.). STZ was dissolved in $1 \mathrm{M}$ of sodium citrate buffer ( $\mathrm{pH}$ 4.5). STZ induces diabetes mellitus within 3-5 days by destroying the beta cells of Langerhans islets in the pancreas. The rats with plasma glucose acclimatize to the animal house environment before beginning of experiment. Rats were fed on the standard chow and drinking water ad libitum throughout the experiment. Room temperature was maintained at $23 \pm 2^{\circ} \mathrm{C}$, the light-dark cycle was on a 12:12 $\mathrm{h}$ $\geq 200 \mathrm{mg} / \mathrm{dL}$ were considered as DM rats and used for experiment (19).

5. Experimental design: Intact and STZ-induced male rats were classified into five equal groups (13 rats, each); intact control (C), diabetic control (DM), diabetic TQ treated (TQ50 and

TQ100), and diabetic insulin treated (DMI) groups. Intact and diabetic control rats were injected with normal saline $(100 \mu 1, s c)$ and drenched with drinking water daily for 42 days. Diabetic TQ treated rats were injected with normal saline $(100 \mu l, s . c)$ and drenched with TQ suspension (50 and $100 \mathrm{mg} / \mathrm{kg}$, b.w.) daily for 42 days. Diabetic insulin treated were injected with insulin (4 IU, s.c) and drenched with drinking water daily for 42. All overnight fasted rats were sacrificed after general anesthesia by combination of xylazine and ketamine $(10 \mathrm{mg}$ and $90 \mathrm{mg} / \mathrm{kg}$, i.p, respectively). Liver, kidney and pancreatic tissue has been removed and fixed in formalin (10\%) for histological examination. 
6. Histological study: According to Luna (20), histological sections have been prepared from pancreas, liver, and kidneys,

\section{Results}

In comparison with pancreatic sections obtained from control male rats (figure 1), thymoquinone treated (TQ50 and TQ100) groups revealed normal cellularity of islets of Langerhans and normal exocrine tissue except few congestion in it (figure 4 and 5), whereas those obtained from non treated and insulin treated diabetic male rats $(\mathrm{DM}$ and $\mathrm{DMI}$ groups) showed complet impairment of some islands and highly destructed of others (figure 2 and 3). Sections obtained from non treated diabetic male rats (DM group) showed sever congestion with thrombi in pancreatic tissue. Other sections showed necrosis in exocrine tissue of pancreas and there is absence of islet of Langerhans. Insulin treated diabetic rats (DMI group) revealed some congestion and the presence of thrombi in the exocrine tissue with the presence of atrophied islet of langerhans.

Normal hepatic architecture with the appearance of radiating shape around the central vein, has been shown in the section obtained from control male rats (figure 6). Also there is normal hepatocytes with

renal convoluted tubules with normal epithelial cells lining these tubules and high stained, and examined under light microscope.

prominent nuclei and profuse cytoplasm. In comparison with control male rats, thymoquinone treated diabetic male rats (TQ50 and TQ100 groups) showed normal hepatic architecture which appear as radiating shape around central vein except few congestion and there is obvious regeneration process and mitotic division in the nuclei of hepatocytes (figures 9 and 10). Insulin treated diabetic male rats (DMI group) revealed normal hepatic architecture which appear as radiating shape around central vein, also there is thrombi in the mildly congested central vein, degeneration of some hepatocytes and loss of hepatic architecture (figure 8). Sections obtained from non treated diabetic male rats (DM group) showed sever congestion, large thrombi in the hepatic tissue, and loss of hepatic architecture with sever hemorrhage, degeneration in hepatocytes, and dilation of sinusoids (figure 7).

Figure (11) showed section obtained from kidney of control male rat, which revealed normal cellularity of glomeruli. Whearas kidney sections obtained from thymoquinone $50 \mathrm{mg}$ 
treated diabetic male rats (TQ50 group) revealed dilation of renal convoluted tubules with normal and high cellularity of glomeruli and tubular basophilia in the epithelial cells of renal tubules (figures 14). Sections obtained from thymoquinone $100 \mathrm{mg}$ treated diabetic

convoluted tubules with normal and high cellularity of glomeruli with tubular basophilia in the epithelial cells of renal tubules (figure 13). Figure (12) showed section of kidney obtained from non treated diabetic male rat which revealed dilation of

\section{Discussion}

Light microscopy investigation of the pancreas of control rats demonstrated normal pancreatic architecture. In contrast, sections of the pancreas from untreated diabetic rats (Group DM) revealed that the islets were relatively small, atrophied, and showed a reduction in the number of polygonal islet cells. Extensive fibrosis was noted in connective tissue areas surrounding blood vessels.

Insulitis was noted in several islets. In the diabetic groups treated with thymoquinone (Groups TQ50 and TQ100), light micrographs revealed lightly stained, small, round islets with a reduced number of polygonal cells compared with the control group. Sections of pancreases obtained from treated rats with thymoquinone (Groups TQ50 and TQ100) male rats (TQ100 group) revealed mild dilation of renal convoluted tubules with normal and high cellularity of glomeruli (figure 15). Sections obtained from insulin treated male rats (DMI group) showed mild dilation of renal renal convoluted tubules with necrosis in the epithelial lining of these tubules, also there is sever hemorrhage in the renal tissue. Other sections showed obvious atrophy in the glomeruli.

revealed islets of a relatively small size and irregular in shape compared with control.

In the present study, light micrographs revealed that streptozotocin altered islet morphology. Moreover, decreased secretory granules, and cytoplasmic vacuolation were noted. These results are in agreement with those reported previously $(21,22)$. The increased lipid peroxidation resulted in disruption of important lipid-containing membranes, including the nuclear envelope, ER membranes, and vacuoles, leading to the observed dilation. Vacuolation and fragmentation of the mitochondria accompained diabetes led to disruption of the antioxidative mechanism, reflecting a limited capacity of the mitochondria to overcome the oxidative stress (23). 
The results of the present study are consistent with previous studies reported increased lipid peroxidation and decreased antioxidant enzymes in diabetes mellitus (13, 15). Kennedy and Baynes (24) suggested that this effect could be due to non-enzymatic glycosylation of proteins and enzymes. Schettler et al. (25) suggested that the reduced antioxidant capacity was due to increased

Histologically, the islets appeared relatively small in size and irregular in shape. In addition, most of the secretory granules appeared empty and the cytoplasm appeared disrupted, with wide intercellular spaces. These findings could be explained by decreased SOD activity and the increase in MDA (26). It is appeared that thymoquinone ameliorated most of the toxic effects of STZ on pancreatic islets, with normal morphology observed in this group. Structurally, the bcells retained their normal structure. This may reflect a compensatory mechanism to adapt to metabolic changes by dividing to supply the energy for the synthesis and secretion of insulin and to increase the production of SOD and other antioxidant enzymes to protect against oxidative stress in b-cells. This is agreement with the biochemical findings of non-significant changes in MDA or lipid

\section{References}

1. Fabricant, D.S.; and Farnsworth, N.R. (2001). The value of plants used in oxygen metabolites, which cause a decrease in the antioxidant defense system. Morphologically, treatment with the thymoquinone indicated partial regeneration of the islet and b-cells, in agreement with the results reported by Kanter et al. (15). These protective effects may be attributed to the antioxidant properties of the thymoquinone, which inhibited lipid peroxidation.

peroxidation and restoration of normal SOD levels. The increased insulin level may be due to the amelioration of the structure of b-cells, including the mitochondria and endoplasmic reticulum.

From the present findings, some questions have been answered about the possible mechanisms of thymoquinone in ameliorating the hyperglycemic effects and regeneration of islets of Langerhan's. So, the present study provided important information concerning the possible therapeutic use of thymoquinone improving diabetic effects of mammals, as the present study propose that drenching of thymoquinone, in a dose of 100 $\mathrm{mg} / \mathrm{kg}$ bw for six weeks, to diabetic male rats (as a model of mammals) significantly improves the hyperglycemia and diabetes control. 
traditional medicine for drug discovery. Environ Health Perspect 109 Suppl 1 6975.

2. Nammi, S.; Boini, M.K.; Lodagala, S.D.; Behara, R.B. (2003). The juice of fresh leaves of

Catharanthus roseus L. reduces blood glucose in normal and alloxan diabetic rabbits. BMC Complement Altern Med, 3: 4.

5. Ali, B.H.; and Blunden, G. (2003). Pharmacological and toxicological properties of Nigella sativa. Phytother. Res., 17(4): 299-305.

6. Al-Ghamdi, M.S. (2003). Protective effect of Nigella sativa seeds against carbon tetrachloride induced liver damage. Am. J. Chin. Med., 31 (5): 721728.

7. Kalus, U.; Pruss, A.; Bystron, J.; Jurecka, M.; Smekalova, A.; Lichius, J.; Kiesewetter, H.

(2003). Effect of Nigella sativa (black seed) on subjective feeling in patients with allergic diseases.

Phytother Res., 17 (10):1209-1214.

8. Salem, M.L. (2005). Immunomodulatory \& therapeutic properties of the Nigella

11. Hosseinzadeha, H.; Parvardeh, S.; Aslb, M.N.; Sadeghnia, H.R.; Ziaee, T. (2007). Effect of thymoquinone and Nigella sativa seeds oil on lipid peroxidation level during global cerebral ischemia-
3. Bukhari, M. (1985). Sahih Bukhari Sharif. Reprint. Lahore Pakistan: Maktaba Rehmania Urdu

Bazar, 3: p312.

4. Nickavar, B.; Mojab, F.; Javidnia, K.; Amoli, M.A. (2003). Chemical composition of the fixed

and volatile oils of Nigella sativa $\mathrm{L}$. from Iran. Z. Naturforsch C., 58(9-10): 629- 631.

sativa L. seed. Intern. Immunopharmacol, 5: $1744-770$.

9. Gilani, A.H.N.; Aziz, I.M.; Khurram, K.S.; Chaudhary, M.; Iqbal, A. (2001). Bronchodilator, spasmolytic and calcium antagonist activities of Nigella sativa seeds (Kalonji): a traditional herbal product with multiple medicinal uses. J. Pak. Med. Assoc., 51: 115-120.

10. Meral, I.; Yener, Z.; Kahraman, T.; Mert, N. (2001). Effect of Nigella sativa on glucose concentration, lipid peroxidation, anti-oxidant defence system and liver damage in experimentallyinduced diabetic rabbits. J. Vet. Med. A. Physiol. Pathol. Clin. Med., 48 (10): 593-599.

reperfusion injury in rat hippocampus. Phytomedicine, 14(9): 621-627.

12. Sultan, T.M.; Butt, M.S.; Anjum, F.M. (2009). Safety assessment of black cumin fixed and essential oil in normal Sprague Dawley rats: Serolological and 
hematological indices. Food. Chem. Toxicol., 47(11):2768-2775.

13. Kanter, M.O.; Coskun, J.; Uysal, H. (2006). The antioxidative and antihistaminic effect of Nigella sativa and its major constituent, thymoquinone on ethanol-induced gastric mucosal damage. Arch .Tox., 80(4): 217-224.

14. Kanter, M. (2009). Effects of Nigella sativa seed extract on ameliorating lung

16. Sayed-Ahmed, M.M. and Nagi, M.N. (2007). Thymoquinone supplementation prevents the development of gentamicininduced acute renal toxicity in rats. Clin. Exp. Pharmacol. Physiol., 34:

399-405.

17. Uz, E.; Bayrak, O.; Uz, E.; Kaya, A.; Bayrak, R.; Uz, B.; Turgut, F.H.; Bavbek, N.; Kanbay, M. and Akcay, A. (2008). Nigella sativa oil for prevention of chronic cyclosporine nephrotoxicity: an experimental model. Am. J. Nephrol., 28: 517-522.

18. Mansford, K.R.; Opie, L. (1968). Comparison of metabolic abnormalities in diabetes mellitus induced by streptozotocin or by alloxan. Lancet, 1 (7544): 670-1.

19. Cakatay, U, and Kayali R., (2006). The evaluation of altered redox status in tissue damage in rats after experimental pulmonary aspirations. Acta. Histochem., 111: 393-403.

15. Kanter, M.; Cosku, N.O.; Korumaz, A. and Oter, S. (2004). Effects of Nigella sativa on oxidative stress and B-cells damage in streptozotocin-induced diabetic rats. The anatomical record part $\mathrm{A}$ : Discoveries in Mol. Cell. And Evol. Bio., 299 (1): 685-691.

plasma and mitochondria of acute and chronic diabetic rats. Clin Biochem; 39 907-12.

20. Luna, L G., Armed Forces Institute of Pathology (U.S.). (1968). Manual of histologic staining methods of the Armed Forces Institute of Pathology. New York, Blakiston Division.

21. Degirmenci, I.; Ustuner, M.C.; Kalender, Y.; Kalender, S.; Gunes, H.V. (2008). The effects of acarbose and Rumex patientia L. on ultrastructural and biochemical changes of pancreatic beta cells in streptozotocin-induced diabetic rats. J. Ethnopharmacol., 97: 555-9.

22. Attia, A.A. (2009). Histological and electron microscopic studies of the effect of beta carotene on the pancreas of streptozotocin (STZ)-induced diabetic rats. Pak. J. Biol. Sci., 12: 301-14. 
23. Soleimani, S.; Azarbaizani, F.F.; Nejati, V. (2007). The effect of Equisetum arvense L (Equisetaceae) in histological changes of pancreatic beta-cells in streptozotocin-induced diabetic in rats. Pak. J. Biol. Sci., 10: 4236-40.

24. Kennedy, L.; and Baynes, J.W. (1984). Non-enzymatic glycosylation and the chronic complications of diabetes: an overview. Diabetologia, 26: 93-8.
25. Schettler, V.; Wieland, E.; Verwiebe, R.; Schuff-Werner, P.; Scheler, F.; Oellerich, M. (1994).

Plasma lipids are not oxidized during hemodialysis. Nephron, 67: 42-7.

26. Abdelmeguid, N.E.; Fakhoury, R.; Kamal, S.M. (2010). Effects of Nigella sativa and thymoquinone on biochemical and subcellular changes in pancreatic bcells of streptozotocininduced diabetic rats. J. Diabetes, 2: 256. 


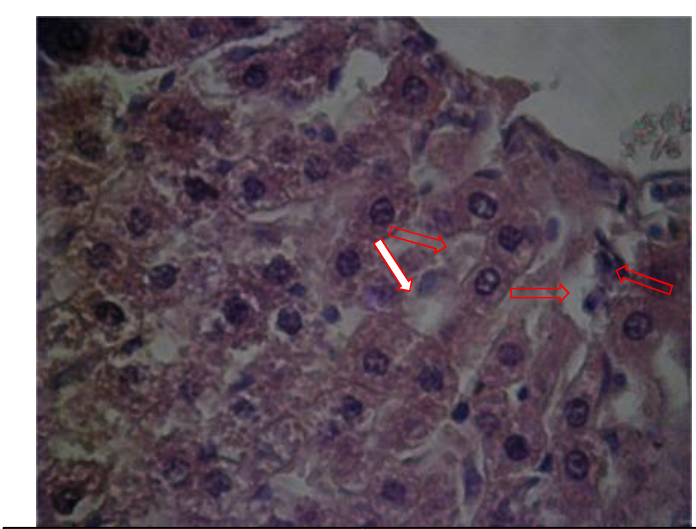

Figure (6): Liver section obtained from conntol male rat shows normal hepatic architecture which appear as radiating shape, also there is normal hepatocytes with prominent nuclei and profuse cytoplasm (white arrows), 200X H\&E.

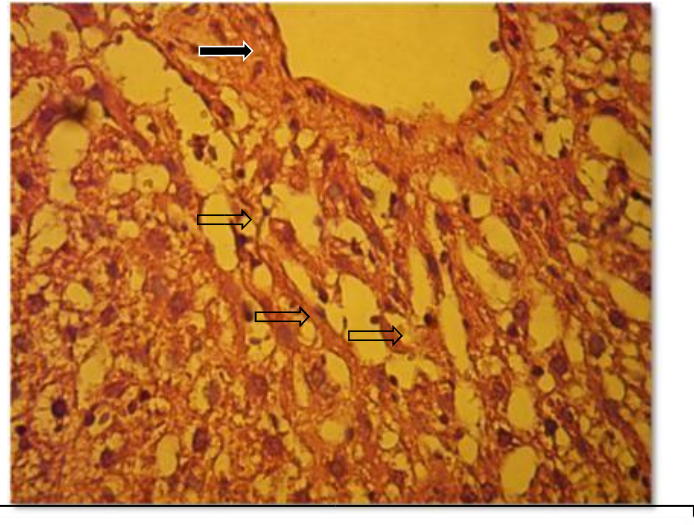

Figure (7): Liver section from non treated diabetic rat shows degeneration in hepatocytes (fatty degeneration) characterized by swelling of hepatocytes and the nuclei locatedat periphery of cells (white arrows). Also there is obvious dilation of sinusoid(black arrow) $200 X$ H\&E.

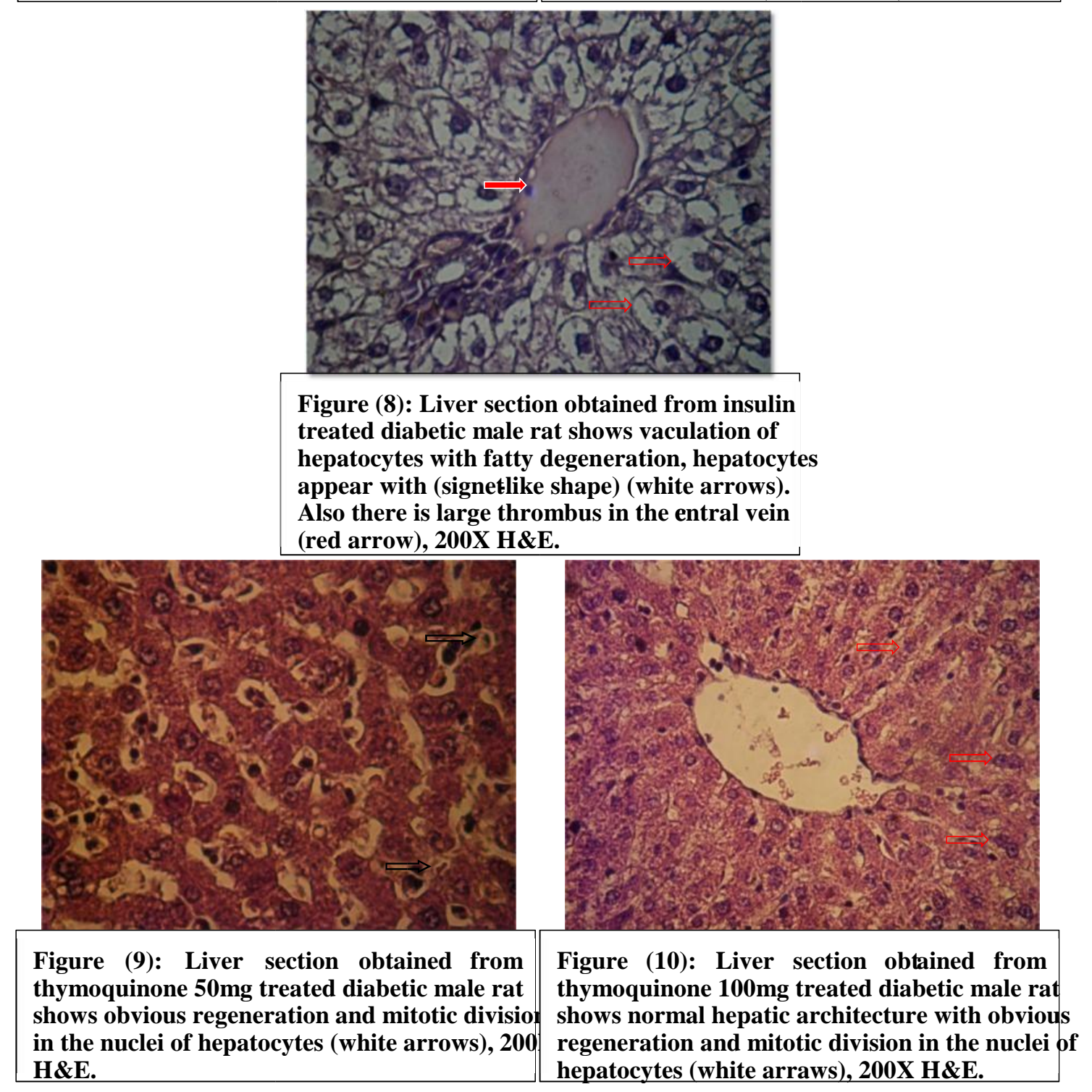




\section{AL-Qadisiyah Journal of pure Science $\quad$ Vol.23 No. 2 Year 2018}

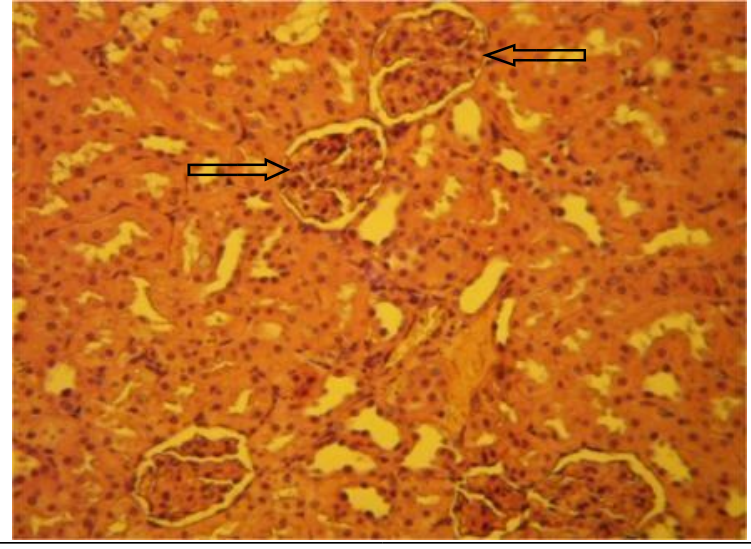

Figure (11): kidney section from control male rat shows normal renal convoluted tubules, normal epithelial cells lining these tubules, and normal and high cellularity of glomeruli (white arrow), 50X H\&E.

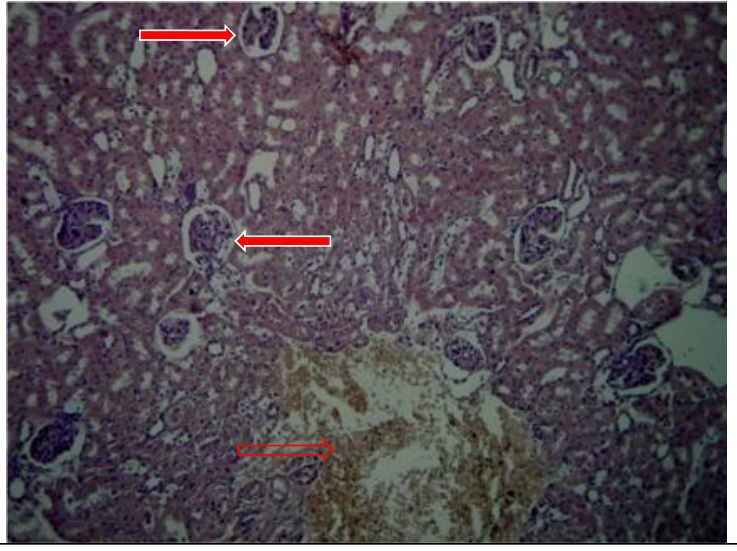

Figure (12): kidney section from non treated diabetic rat shows dilation of renal convoluted tubules (red arrows) with necrosis in the epithelial lining of these tubules, also there is sever hemorrhage in the renal tissue, $50 X$ H\&E.

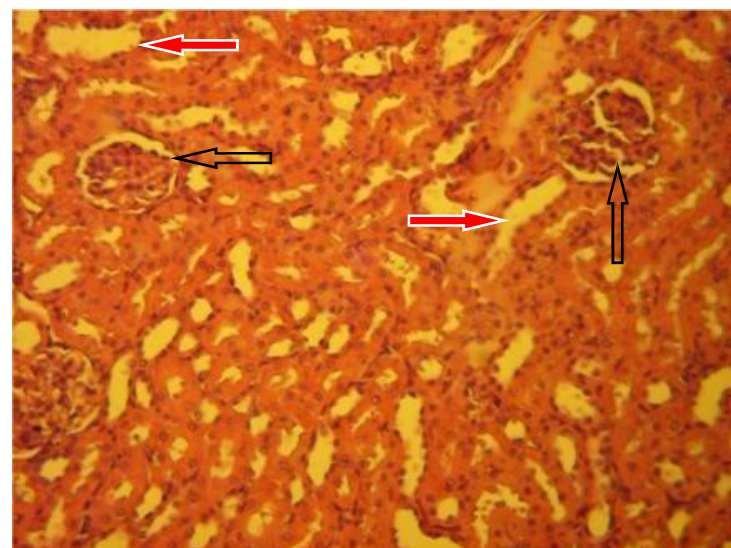

Figure (13): kidney section obtained from insulin treated diabetic male rat sho ws mild dilation of renal convoluted tubules (red arrows) with normal and high cellularity of glomeruli (white arrows), $50 X$ H\&E.

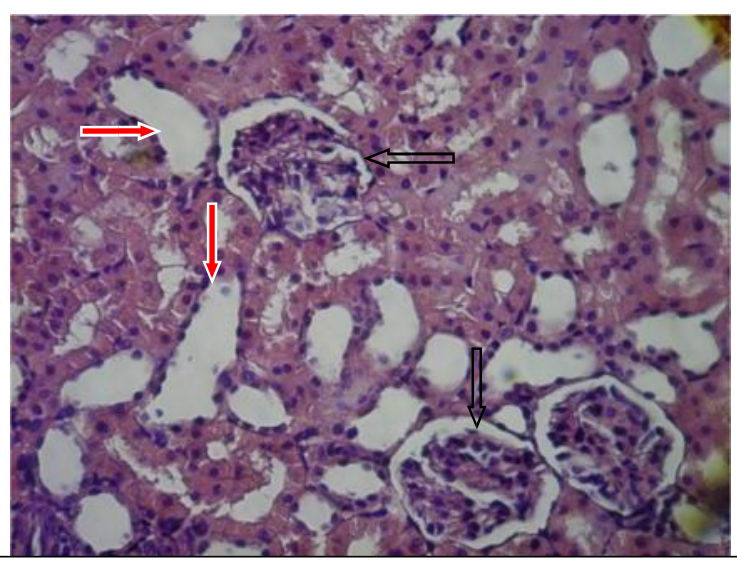

Figure (14): kidney section from thimoquinone $50 \mathrm{mg}$ treated male rat shows dilation of renal convoluted tubules (red arrows), high cellularity of glomeruli (white arrows) and tubular basophilia in the epithelial cells lining the renal tubules, 50X H\&E.

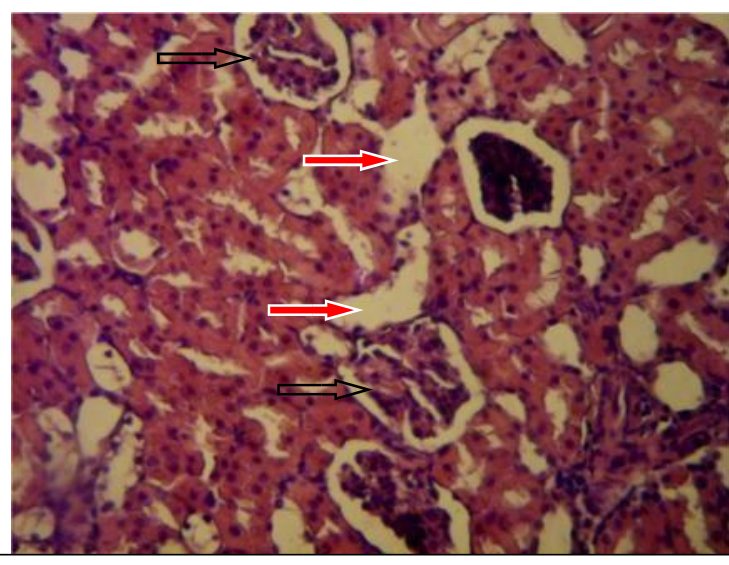

Figure (15): kidney section obtained from thimoquinone $100 \mathrm{mg}$ treated male rat shows mild dilation of renal convoluted tubules (red arrows) with normal and high cellularity of glomeruli (white arrows), 50X H\&E. 


\section{AL-Qadisiyah Journal of pure Science $\quad$ Vol.23 No. 2 Year 2018}

التغيرات النسجيةـ المرضية لبنكرياس وأكباد وكلى ذكور الجرذان المستحث فيها داء السكري والمعالجة بالثايموكوينون

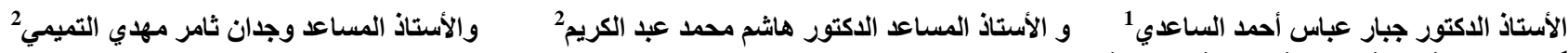

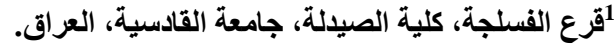
2قتم علوم الحياة، كلية العلوم، جامعة القادسية، العراق.

الخلاصة

أجريت الد ارسة الحالية بهدف تقييم فعالية الثايموكوينون في تلطيف التغى ارت النسجية-المرضية لبنكرياس وأكباد وكلى ذكور الجرذان المستحث فيها داء السكري تجريبيا باستخدام عقار الستربتوزوتوسين. أجريت الد ارسة الحالية باستخدام 65 جرذاً ذك

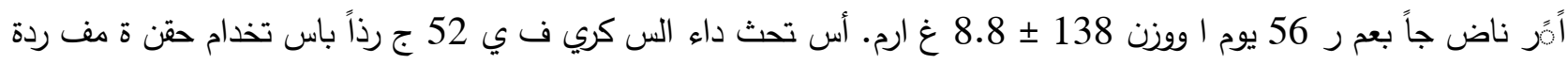
م ن عق ار الستربتوزوتوسين( 60 ملغم/كغم من وزن الجسم في البريتون). تم التأكد من حدوث داء السكري عن طريق في فياس

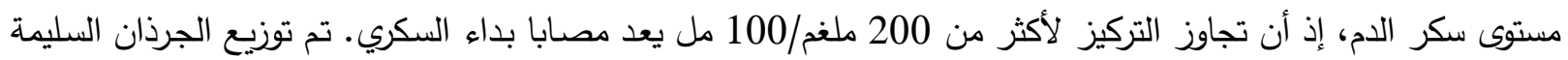

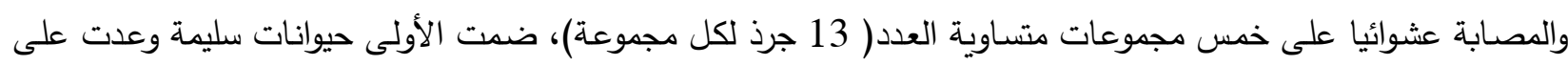
أنها مجموعة سيطرة (C) وجرعت ماء الشرب وحقنت بالمحلول الفسلجي يومياً، وضمت المجموعات الأخرى حيوانات مصابة إذ

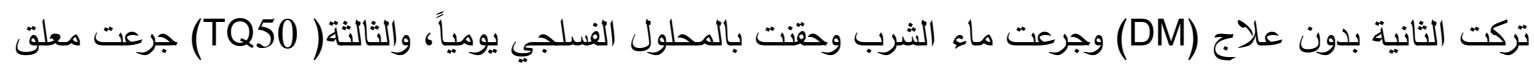

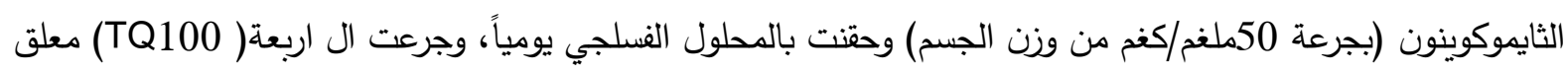

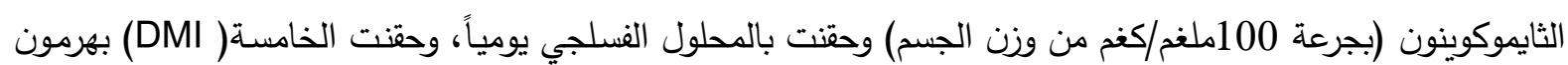
الانسولين (بجرعة 4 وحدات دولية لكل حيوان) وحقنت بالمحلول الفسلجي يومياً. استمرت الد ارسة لمدة 6 أسابيع. بعد مرور

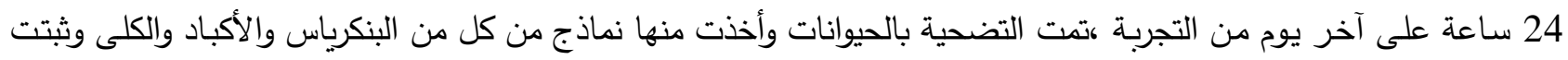
في الفورمالين( 10\%) لغرض الد ارسة النسجية-المرضية.

بينت النتائج تحسناً في معالم التغيارت المرضية لأنسجة البنكرياس في كلتا منطقتي الافارز الخارجي والصمي (جزر لانكرهانس) لذكور الجرذان المصابة بداء السكري ج ارء المعالجة بالثايموكوينون، كما بينت الد ارسة أن هذا التحسن كان ايجابياً مع تقدم مدة المعالجة، إذ أظهر الفحص النسيجي لمقاطع البنكرياس المأخوذة من من ذكور الجرذان المصابة بداء السكري والمعالجة بالثايموكوينون تغى ارت مرضية طفيفة تمثلت بوجود بعض الاحتقان في حين سجلت نتائج المجموعة المصابة وغير المعالجة ضراًةر كبى اًةًر ف ي بع ضل ج زر لانكره انز م ع ال تحطم الكام ل لل بعض الآخ ر. أم ا أنس جة الكب د ل ذكور الج رذان المص ابة والمعالج ة بالثايموكوينون فقد أظهرت هي الأخرى مظه أَر طبيعياً متمثلاً بوجود الثكل الثعاعي لترتيب حبال الخلايا الكبدية حول الوريد المركزي مع وجود بعض النزف والتتكس إلا أن الخلايا الكبدية تبدو في م ارحل انقسام خيطي وافر ، في حين عانت أكباد الحيوانات المصابة وغير المعالجة من احتقان شديد مع وجود خثر بين الخلايا الكبدية مع اختفاء الترتيب الطبيعي للحبال الكبدية مع تنكس في بعض الخلايا الكبدية وتوسع في الجيبانيات الكبدية. كما أشارت المقاطع المأخوذة من أنسجة كلى ذكور الجرذان المصابة بداء السكري والمعالجة بالثايموكوينون الى معالم طبيعية بالنفرونات الكلوية وبطانة نبيباتها بينما عانت كلى ذكور الجرذان المصابة وغير المعالجة من توسع في النبيبات الكلوية مع تتكس بطانتها مع وجود نزف شديد في أنسجة الكلية. يستتج من الد ارسة الحالية أن تجريع ذكور الجرذان بمعلق الثايموكوينون( 100 ملغم/كغم من وزن الجسم) له تأثير فعال في تحسين وزيادة تجديد أنسجة البنكرياس والكبد والكليتين لذكور الجرذان المصابة بداء السكري. 